\title{
CORRIGENDUM
}

\section{An enigmatic Arthropoda from the Upper Triassic (Carnian) southwestern Gondwana (Argentina) - CORRIGENDUM}

María B. Lara, Bárbara Cariglino, Ana M. Zavattieri, and Iracema Zacarías

doi:10.1017/jpa.2019.86, Published by Cambridge University Press, 25 October 2019.

On the second page of the article by Lara et al. (2019) in the Systematic paleontology section, the Genus Duraznovis was misspelled in the introduction of the new genus.

The authors apologize for the error.

\section{Reference}

Lara, M. B., Cariglino, B., Zavattieri, A. M., and Zacarías, I., 2019, An enigmatic Arthropoda from the Upper Triassic (Carnian) southwestern Gondwana (Argentina): Journal of Paleontology, doi: 10.1017/jpa.2019.86. 